\title{
Comment
}

\author{
Ian R. Harper
}

\begin{abstract}
Y INCE Vince FitzGerald and I are coauthors of two papers on the subject of saving, it should not be surprising that I agree with many of his points. But even coauthors are allowed to differ; and we do so on the importance of the current account deficit in the debate over national saving and on the role of taxpreferred private savings vehicles.
\end{abstract}

\section{National Saving and the Current Account}

In my view, the main argument for raising national saving is to raise national investment and the rate of economic growth. Here I am in complete agreement with FitzGerald that the evidence speaks strongly in favour not just of a coincidence of high rates of national saving and investment but of a causal link between the two. The link may well be bi-directional: high national saving facilitates high national investment, and is facilitated by it as investment promotes higher rates of economic growth and higher levels of national income.

But I do not see why higher national saving will, by itself, reduce the external deficit. Nor do I see this as the primary purpose of raising national saving. FitzGerald expresses confidence (p.8) that 'policies which do succeed in lifting national saving will also lift national investment (and as well reduce the external deficit) .. ․ But why should the increase in national saving produce a smaller increase in national investment - which it would have to if it were to reduce the nation's call on foreigu savings and hence the current account deficit? After all, our experience in the second half of the 1980s was precisely the contrary: the increase in national saving engineered by the government through an historic rise in public saving touched off an even greater rise in national investment (primarily private) which increased the current account deficit. Indeed, it was this increase in the extemal deficit which, I believe, finally broke the government's resolve, inducing it to tighten monetary policy and precipitate the 'recession we had to have'.

like many others of his persuasion, FitzGerald argues from a desired target for national investment (say, 25 per cent of GDP) through a perceived upper limit to the current account deficit (say, 3 per cent of GDP) to a resultant desired level of national saving (22 per cent of GDP). But this allows the tail (the external deficit) to wag the dog (national saving). By FitzGerald's own argument, we should start with a higher level of national saving. This should induce higher national investment and Melbourne Business School within the University of Melbourne. 
economic growth. Surely these are worth having regardless of the resultant effect on the current account deficit. After all, even if the current account deficit were to rise, the investment would be private ('consenting adults') and would eventually bring higher levels of national saving (and a lower external deficit) in its train.

Allowing the current account deficit to constrain the acceptable savinginvestment differential creates two problems. The first is that wealth-enhancing investment opportunities are needlessly discarded. Imposing a current account constraint implies that only those investment projects which can be financed within the constraint promote national welfare, whereas any and all private projects which show positive net discounted cash flows, irrespective of their impact on the current account deficit, are wealth-increasing. This explains why, notwithstanding the increase in the current account deficit over the 1980s, recent Australian Bureau of Statistics figures show that the net worth of the Australian economy increased during this period (ABS, 1995).

The second problem is tactical. FitzGerald and others who emphasise an external constraint sensitise the voting public and politicians to the current account deficit. If national investment then rises faster than expected following a rise in national saving, government is left with no altenative but to engineer macroeconomic restraint. Such an outcome, as it did in Australia in the late 1980s, inevitably unravels all the good work done to raise national saving in the first place.

FitzGerald is right to promote higher national saving and right to argue that this will raise national investment and economic growh. He slould be prepared to accept whatever national investment such a policy delivers, in full recognition that such investment is privately underwritten and that it will eventually promote even higher levels of saving as national income grows. To allow the current account deficit to limit the growth of investment needlessly sacrifices wealth-enhancing investment opportunities at best, and at worst invites a macroeconomic backlash which undermines efforts to raise national (especially public) saving.

\section{Tax-preferred Private Saving Vehicles}

FitzGerald also devotes considerable space to a defence of tax-preferred private savings vehicles: IRAs and the like. This is a theme to which a number of Australian banks faced with increasing competition from tax-preferred superannuation products also warm. FitzGerald is at pains to point out that, provided tax is eventually collected when the funds are withdrawn at the same rate as would otherwise have been paid when they were deposited, the present value of tax collected is the same. Moreover, if the funds invested earn a higher rate of return than the government is obliged to pay on borrowed funds while it waits for the tax to be paid, the tax office may actually come out in front.

I have no difficulty with the logic of this position; indeed, it is unexceptionable. My problem is with the pragmatics of a proposal which might, at best, produce a modest increase in private saving and no reduction in public saving but which could, at worst, produce no increase in private saving and a substantial reduction in public 
saving. In this latter case, the provision of tax-preferred savings vehicles actually reduces national saving.

While FitzGerald's proposition is correct in principle, the practical outworking in the current Australian context is that tax privileges presently enjoyed by superannuation funds would be extended to certain classes of bank deposits. Under present arrangements, the effective tax rate on superannuation saving is lower than that on any other savings vehicle with the exception of housing. If one includes the fact that it is still too easy to arrange superannuation pay-outs in a form which preserves entitlement to the public old-age pension and associated benefits, I suggest it is not at all clear that public tax expenditures on subsidising superannaution saving are eventually recouped.

Superamuation saving receives a net public subsidy, as would other forms of private saving if they were granted access to the same privileges. If, as FitzGerald suggests, the offset even from compulsory superannuation is substantial in the longer run, this leaves tax-preferred superanmuation making a negative net impact on national saving.

Of course, it is difficult to be dogmatic on this score because we simply do not know enough about the relationships between public and private saving and between superannuation and alternative forms of private saving. Given that most observers acknowledge that higher public saving is generally the key to higher national saving, I, for one, am particularly wary of proposals which risk an almost certain sacrifice of public saving to achieve uncertain benefits in terms of additional private saving. We simply cannot afford to throw public saving away. 1

Moreover, if Hutchison's (1992) results are to be believed, raising public saving by cutting public expenditure produces little if any reduction in private saving and therefore raises national saving directly. With uncertainty surrounding the net impact of tax-preferred savings schemes and some assurance that higher public saving will raise national saving, why would anyone risk the candle?

In this regard, I think the experience of New Zealand bears closer examination. The New Zealand government produced tax neutrality amongst its savings instruments by moving them all on to a classical footing, by eliminating tax preferences for life insurance and superannuation, in particular, and treating them the same as bank deposits and interest-bearing securities. Although this goes right against the expenditure-tax treatment of saving advocated by FitzGerald, there las been no noticeable collapse of national saving in New Zealand. Indeed, the New Zealand current account deficit has moved in a direction entirely congenial to FitzGerald and the New Zealand economy is enjoying high levels of national investment.

\footnotetext{
${ }^{1}$ A recent survey of the US evidence on tax-prcfencel savings schemes (McCarthy \& Pham, 1995:5) reaches a similar conclusion: 'As for IRAs in general, the short-1un effect of these accounts on savings is diflicult to establish, but any increase in savings is likely to be extremely modest. An IRA program maintaincd over the long term is also likely to have a small impact, although it might increase savings at the margin. . . a major tunaround in the national saving rate will require much more ambitious initiatives: a total overhaul of the tax system to favour all savings, a lange-scale eflort to reduce the budget deficit, or a signilicant chrange in houschold attitudes towards saving.'
} 
Given the evidence as it stands, we can be much more confident that tax preferences will change the form in which people save than we can about their impact on the overall level of saving (private as well as national). If caution suggests we treat tax privileges as likely to lower national saving, logic compels us to view the elimination of such privileges as likely to increase national saving, if anything.

A further implication is that a generalised move towards expenditure-tax treatment of saving is likely, at least in the short to medium term, to lower national saving, whereas a move towards classical tax treatment of all forms of saving (including housing) would almost certainly raise national saving. While I have a great deal of sympathy for the 'ideal' properties of an expenditure tax, I suspect one of the main reasons why it has never been implemented is that the initial cost to public revenue (read public saving) is too high. It would be much easier to contemplate from a position of fiscal strength. New Zealand may yet show us the way on this as on so many other fronts by using the amassed fiscal surpluses in prospect to 'purchase' expenditure-tax treatment of saving.

\section{References}

Australian Bureau of Statistics (ABS) (1995), National Balance Sheets for Australia: Issues and EXperimental Estimates 1.989-1.992, Canlserra (Cat. No. 5241.0).

Hutchison, M. (1992), 'Budget Policy and the Decline of National Saving Revisited', Bank for International Settlements, Basle (BIS Economic Papers No. 33).

McCathy, J. \& H. Pham (1995), 'The Impact of Individual Retirement Accounts on Savings', Current Issues in Eronomics and Finance 1(6): 1-6. 